\title{
The Determinants of Country Risk Premium Volatility: Evidence from a Panel VAR Model
}

\section{Petra Palić}

The Institute of Economics, Zagreb, Croatia

ppalic@eizg.hr

\section{Petra Posedel Šimović}

Zagreb School of Economics and Management, Zagreb, Croatia pposedel@zsem.hr

\section{Maruška Vizek}

The Institute of Economics, Zagreb, Croatia

mvizek@eizg.hr

\author{
CroEconSur \\ Vol. 19 \\ No. 1 \\ June 2017 \\ pp. 37-66
}

Received: January 8, 2017

Accepted: March 14, 2017

Research Article

doi:10.15179/ces.19.1.2

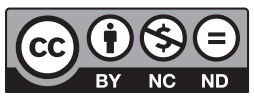

\section{Abstract}

We use data for 24 European countries, spanning from 1994 to 2015, in order to examine how changes in macroeconomic conditions influence country risk premium volatility proxied by sovereign spreads variance. In the first part of the empirical analysis, we estimate the univariate generalized autoregressive conditional heteroskedasticity (GARCH) model in order to obtain the conditional variance of sovereign bond spreads. We show that an increase in this variance coincides with economic and financial crisis occurring either in the country or globally. In the second part of the empirical analysis, we estimate the panel vector autoregression (panel VAR) model in order to model the interplay between macroeconomic fundamentals (inflation, output gap, public debt and interest rates) and the country's risk premium volatility. We show that overheating of the economy, along with an unexpected increase in public debt, inflation and 
interest rates, increase the country's risk premium volatility. We also show that a sudden increase in the country's risk premium volatility depresses the economy, exerts deflationary pressures on consumer prices, and is followed by a strong and permanent increase in public debt.

Keywords: sovereign bond markets, panel VAR, European Union

JEL classification: C33, E44, F34, G15

\section{Introduction ${ }^{1}$}

Sovereign spreads are defined as differentials between yields on government bonds and yields on what is considered a risk-free government bond of comparable maturity. Consequently, sovereign spreads are widely considered a measure of the risk premium, which is defined as compensation to creditors for the risks of holding a risky asset until maturity. Sovereign spreads are thus associated with a country's probability of default on its debts. This in turn suggests that as economic and political conditions of a country change, so does its risk premium. The seminal work of Edwards $(1984 ; 1986)$ indicates that country risk does play an important role in the bond market, as he finds evidence that sovereign spreads are positively associated with country risk. The theory developed by Edwards (1986) indicates that since country premiums are influenced in the long run by the size of public debt, internal and external imbalances, international reserves and wealth, one should expect macroeconomic fundamentals to influence the country's risk. Thus Edwards (1984) develops a model in which the probability of default and the probability of loss in the case of default determine sovereign spreads. The probability of default is represented by external debt sustainability, which is in turn measured by indicators of liquidity and solvency. In this way, macroeconomic variables are used to reflect liquidity and solvency of a country

1 This work was supported by the Croatian Science Foundation under project 1356 - Economic, statistical and political aspects of sovereign bond markets. 
and in the same vein the probability of default. However, one must also note that the work undertaken by Edwards (1984) is based on previous advances made by Feder and Just (1977), Eaton and Gersovitz (1980) and Sachs (1981). Thereby Eaton and Gersovitz (1980) focus on the behavior of lesser developed countries in financial markets, with special emphasis on the role played by debt and international reserves, while Feder and Just (1977) look at the importance of various economic factors in determining the debt servicing capacity of borrowing countries.

Experience teaches us that risk premiums proxied by sovereign spreads tend to exhibit substantial variation, both across countries and over time. For example, Hilscher and Nosbusch (2010) use a dataset of 31 countries over the period from 1994 to 2007 and demonstrate that variation in country fundamentals explains a large share of the variation in emerging market sovereign debt prices. Furthermore, they find that one standard deviation growth in the volatility of terms of trade is associated with an increase of 164 basis points in spreads. On the other hand, Bernoth, Von Hagen and Schuknecht (2006) use a dataset of issue spreads in the US and DM (euro) bond market to provide a study of bond yield differentials among EU government bonds issued between 1993 and 2005 . They examine whether government bond yield differentials in EU countries are determined by credit risk and liquidity effects, and whether the EMU has had a significant impact on bond pricing. The results indicate that yield spreads react significantly to measures of government indebtedness, both before and after the start of the EMU.

The last decade, characterized by the Great Recession and the European debt crisis, has demonstrated how the variation in countries' risk premiums can bring forth adverse economic consequences. The findings on European government bonds presented by Codogno, Favero and Missale (2003), Barrios et al. (2009), Sgherri and Zoli (2009), Manganelli and Wolswijk (2009) and Favero, Pagano and Von Thadden (2010) suggest that the international risk factor was an important determinant of bond yields and spreads for the period before the 
summer of 2007. As expected, that effect was more intensive during periods of contracting international financial conditions (Haugh, Ollivaud and Turner, 2009; Barrios et al., 2009) and more distinct in countries with high levels of public debt (Codogno, Favero and Missale, 2003).

Due to these developments, the economic literature witnessed a renewed interest in examining sovereign bond spread determinants. Studies like Baldacci, Gupta and Mati (2008), Ebner (2009), Von Hagen, Schuknecht and Wolswijk (2011), Dumičić and Ridzak (2011), Aizenman, Hutchison and Jinjarak (2013) and Seungyeon, Young and Byoung (2013) build on the seminal work of Edwards (1984) and examine whether macroeconomic, fiscal and financial market variables influence sovereign bond spreads. Min et al. (2003), for example, investigate the significance of solvency and liquidity in determining bond spreads in emerging economies. This study demonstrates that in the 1990s the solvency and liquidity variables explain most of the spread variations in emerging markets. Also, they show that US interest rates and macroeconomic fundamentals have a significant role in the determination of bond spreads.

An extension of this literature, represented by studies like Dell'Ariccia, Schnabel and Zettelmeyer (2002), Bellas, Papaioannou and Petrova (2010), Alexopoulou, Bunda and Ferrando (2010), Ivanov, Tkalec and Vizek (2011) and Tkalec, Vizek and Verbič (2014), focuses on disentangling the short- and long-run effects of macroeconomic and financial market factors on sovereign spreads. Another strand of literature (Berganza, Chang and Herrero, 2004; Malone, 2009; Tkalec, Vizek and Verbič, 2014) applies the collateral value concept of Kiyotaki and Moore (1997) to sovereign spreads determination, thereby postulating that the cost of borrowing falls as the value of the collateral increases.

In general, the reviewed studies conclude that sovereign spreads are influenced by changes in external debt, fiscal balance and stance, current account balance, public debt, inflation and reserves. If the studies differentiate short- from longterm effects, then usually economic fundamentals matter more in the long run, 
while in the short run financial market conditions have a prevailing role in determining sovereign spreads. Although some empirical consistencies do exist, and they usually hold for specific regions or time periods, the debate about the determinants of sovereign bond spreads is far from being settled.

We extend the existing literature by choosing to focus on the determinants of sovereign spread volatility, instead of sovereign spreads. Most of the literature implicitly recognizes that market conditions, especially market volatility, determine much of the overall spread movements. Studies such as Ebner (2009), Beber, Brandt and Kavajecz (2009), Bellas, Papaioannou and Petrova (2010), Alexopoulou, Bunda and Ferrando (2010), Dumičić and Ridzak (2011) and Tkalec, Vizek and Verbič (2014) thus control directly for market volatility using the VIX or DAX volatility index. However, by doing that, most of the variance of sovereign spreads is naturally explained by market volatility as volatility indices are usually the only heteroscedastic explanatory variable in a model seeking to examine the determinants of sovereign spreads which are also heteroscedastic. Not surprisingly, if used in empirical studies, volatility indices usually emerge as the single most important explanatory variable in sovereign spread models, thus precluding us from establishing whether economic fundamentals influence economic uncertainty represented by sovereign spreads variance. This problem is also a natural consequence of the method of choice in empirical sovereign spreads studies; all the reviewed studies except Seungyeon, Young and Byoung (2013) use panel data models. As panel data models are designed to explain the mean spread value and not its variance, the determinants of sovereign spreads variance in panel data studies are almost completely ignored. This problem is also present in panel studies that do not control for market volatility, as panel data models are in effect not designed to model heteroscedastic series. However, as sovereign spreads variance is of crucial importance for public debt management and is the true reason why countries end up in sovereign debt crisis, one cannot afford not to understand how fundamentals affect sovereign spreads volatility and thus contribute to changes in uncertainty associated with country risk premiums. 
In order to understand how fundamentals affect sovereign spreads volatility, we estimate univariate generalized autoregressive conditional heteroskedasticity (GARCH(1,1)) models with the aim of obtaining the estimate of conditional variance of sovereign bond spreads. We use the estimated variance in a panel vector autoregression model (VAR) along with output gap, public debt, interest rates and inflation in order to examine how changes in business cycle developments, fiscal policy, monetary policy and inflation affect sovereign spreads volatility. As panel VAR needs to satisfy the stability condition, we focus only on the shortrun analysis. Using panel VAR for this purpose not only enables us to track how changes in economic fundamentals influence sovereign spreads variance over time, but it also allows us to examine whether changes in sovereign spreads variance can influence real economic outcomes. The rest of the paper is organized as follows. Section 2 presents the data. Section 3 explains the methodology, while Section 4 discusses the empirical results. Section 5 concludes the paper.

\section{Data}

The first part of this research uses weekly data based on a combination of the government bond spreads and Emerging Market Bond Index (EMBI) for 24 European Union countries. The EMBI spread is a typical and widely used proxy for sovereign spreads calculated by Morgan Stanley for emerging countries' sovereign bonds, while government bond spreads are a metric provided by the Bloomberg database. We are forced to combine data for sovereign bond spreads from two different sources because Bloomberg does not provide its own government bond spreads indicator for European emerging countries. For Germany, we use five-year sovereign bond yields instead of spreads, because Germany itself is a benchmark country for calculating spreads.

We use first differences of government bond spreads in order to estimate the conditional variance of the government bond markets for Austria, Belgium, Bulgaria, Croatia, Czech Republic, Denmark, Finland, France, Germany, 
Greece, Hungary, Ireland, Italy, Latvia, Lithuania, Netherlands, Poland, Portugal, Romania, Slovakia, Slovenia, Spain, Sweden and United Kingdom. As our study has broad country coverage, data time span varies between countries. As a rule, we use the longest available data range for each country in order to capture as many economic cycles as possible. In general, data ranges for the emerging economies are much shorter than for the developed economies, and are available mostly from the 2000s onwards. Slovakia has the shortest data range, where data are only available from the third quarter of 2013 to the first quarter of 2015. On the other hand, bond spreads for Denmark, Finland, France, Germany and Spain are available from the first quarter of 1994 to the first quarter of 2015. For many other developed European countries, government bond spreads are available from the late 1990 s to the first quarter of 2015.

Table 1 displays basic descriptive statistics for government bond spreads. Austrian, Dutch, French and Swedish spreads stand out with the lowest means and standard deviations. On the other hand, emerging countries are characterized by higher means and standard deviations. In that regard Croatian, Latvian and Lithuanian spreads are particularly striking. As far as the distribution of spreads is concerned, the majority of the analyzed spreads are positively skewed, with German, Romanian and Slovenian spreads being the most notable exception. Further on, all spread distributions, except Belgian and Finnish, are platykurtic. As expected, normality test results suggest that all spread distributions deviate from the standard Gauss distribution.

In the second part of our empirical analysis, we use a quarterly panel VAR model in order to assess short-run interactions between conditional volatility of sovereign spreads $\left(\operatorname{cond} v_{t}\right)$ and four macroeconomic variables: output gap $\left(\right.$ outputgap $\left._{t}\right)$, harmonized consumer price inflation $\left(p_{t}\right)$, public debt $\left(\right.$ pdebt $\left._{t}\right)$ and referent interest rates $\left(i r_{t}\right)$. Weekly estimates of conditional volatility are transformed to quarterly frequency using the arithmetic mean. Output gap is calculated as the difference between actual and potential GDP, whereby potential GDP is estimated using the Hodric-Prescott filter and expressed as a percent of 
actual GDP. The source for real GDP, consumer price index and public debt series is Eurostat, while interest rates were collected from the International Financial Statistics database. Conditional volatility enters the panel VAR model in log levels (as it is by definition stationary), while macroeconomic series are first transformed to logarithms (if they are not already expressed in percentages) and then differenced.

Table 1: Government Bond Spreads - Descriptive Statistics

\begin{tabular}{|c|c|c|c|c|c|c|c|}
\hline Country & $\begin{array}{c}\text { GBS/ } \\
\text { EMBI }\end{array}$ & Observations & Mean & $\begin{array}{l}\text { Standard } \\
\text { deviation }\end{array}$ & Skewness & $\begin{array}{c}\text { Excess } \\
\text { kurtosis }\end{array}$ & Normality \\
\hline Austria & GBS & 830 & 0.28 & 0.28 & 1.33 & 2.59 & $283.0[0.00]$ \\
\hline Belgium & GBS & 830 & 0.46 & 0.50 & 2.04 & 5.20 & $942.6[0.00]$ \\
\hline Bulgaria & EMBI & 678 & 1.7 & 1.03 & 0.43 & 0.04 & $26.6[0.00]$ \\
\hline Croatia & EMBI & 783 & 2.08 & 1.41 & 0.71 & -0.16 & $144.9[0.00]$ \\
\hline $\begin{array}{l}\text { Czech } \\
\text { Republic }\end{array}$ & GBS & 422 & 0.80 & 0.54 & 0.53 & -0.56 & $59.6[0.00]$ \\
\hline Denmark & GBS & 1108 & 0.37 & 0.42 & 1.55 & 2.11 & $982.2[0.00]$ \\
\hline Finland & GBS & 1108 & 0.52 & 0.96 & 2.61 & 5.46 & $5877[0.00]$ \\
\hline France & GBS & 1108 & 0.26 & 0.29 & 1.42 & 2.00 & $688.2[0.00]$ \\
\hline Germany & GBS & 1108 & 3.40 & 1.71 & -0.28 & -0.55 & $47.4[0.00]$ \\
\hline Greece & GBS & 422 & 7.72 & 7.67 & 1.35 & 1.25 & $307.9[0.00]$ \\
\hline Hungary & EMBI & 798 & 1.85 & 1.59 & 1.00 & 0.08 & $388.8[0.00]$ \\
\hline Ireland & GBS & 804 & 1.52 & 2.29 & 1.59 & 1.27 & $1356[0.00]$ \\
\hline Italy & GBS & 804 & 1.04 & 1.17 & 1.55 & 1.60 & $962.2[0.00]$ \\
\hline Latvia & EMBI & 798 & 4.93 & 2.35 & 1.14 & 1.07 & $315.8[0.00]$ \\
\hline Lithuania & EMBI & 282 & 2.34 & 0.98 & 0.52 & -0.75 & $49.3[0.00]$ \\
\hline Netherlands & GBS & 830 & 0.18 & 0.16 & 1.14 & 1.56 & $236.7[0.00]$ \\
\hline Poland & GBS & 831 & 3.03 & 1.56 & 1.21 & 1.05 & $420.6[0.00]$ \\
\hline Portugal & GBS & 830 & 1.83 & 2.77 & 1.86 & 2.64 & $1547.2[0.00]$ \\
\hline Romania & GBS & 251 & 3.22 & 1.18 & -0.1 & -1.24 & $30.6[0.00]$ \\
\hline Slovakia & GBS & 671 & 0.84 & 0.77 & 0.14 & 0.41 & $6.7[0.044]$ \\
\hline Slovenia & GBS & 212 & 3.27 & 1.35 & -0.33 & -1.48 & $69.9[0.00]$ \\
\hline Spain & GBS & 1108 & 1.25 & 1.48 & 1.11 & -0.03 & $913.5[0.00]$ \\
\hline Sweden & GBS & 429 & 0.11 & 0.26 & 0.30 & -0.47 & $16.8[0.0002]$ \\
\hline UK & GBS & 1108 & 0.72 & 0.48 & 0.24 & -0.89 & $86.3[0.00]$ \\
\hline
\end{tabular}

Source: Authors' calculations. 


\section{Modelling Strategy}

The modelling strategy employed in this paper consists of two steps. In the first step, we obtain conditional variance of sovereign bond spreads using the univariate GARCH $(1,1)$ model. The basic idea of the GARCH $(1,1)$ model is that the conditional variance has an autoregressive structure and has to be positively correlated with past values. Also, an important advantage of this model is the possibility to describe a large number of financial series quite accurately. Although this model is designed to forecast for just one period, it turns out that based on the one-period forecast, a two-period forecast can be made. Finally, by replicating this step, long-horizon forecasts can be designed. Also, for the GARCH $(1,1)$ model, the distant-horizon forecast is equal for all periods as long as $\alpha+\beta<1$. Accordingly, GARCH models are conditionally heteroskedastic and mean reverting, but at the same time they display a constant unconditional variance (Engle, 2011).

In the second step, we employ panel VAR in order to assess whether macroeconomic outcomes affect the volatility of country risk, and to examine under which conditions changes in country risk volatility produce real economic consequences. The panel VAR model combines two approaches: the traditional VAR approach, which treats all the variables in the system as endogenous, and the panel data approach, which allows for unobserved individual heterogeneity (Love and Zicchino, 2006). After all the coefficients of the panel VAR are estimated, the impulse response functions and variance decompositions are calculated. The panel VAR model is widely recognized and typically used in macroeconomic and macro-finance studies rather than microeconomic studies (Canova and Ciccarelli, 2013). For example, Assenmacher-Wesche and Gerlach (2008) investigate the relationships between inflation, economic activity, credit, monetary policy, residential property and equity prices in 17 OECD countries using a panel VAR model. On the other hand, Boubtane, Coulibaly and Rault (2013) empirically demonstrate the interaction between immigration and host country economic conditions employing a panel VAR methodology. 
The evaluation of risk of financial assets is based on statistical models describing underlying asset prices and their volatilities, namely deviations of asset prices from their expected values. Since the volatility of an asset is not observable, it needs to be modelled. Empirically, conditional first and second moments of asset returns are time-varying, and this stylized fact must be accounted for in the modelling framework. In fact, during periods of market stress (political changes or disorders, economic crises, but also changes that are not so drastic, e.g., announcements of macroeconomic data), prices of financial assets fluctuate greatly and the volatility changes over time, i.e., the process of interest is heteroscedastic. Therefore, in the modelling procedure, we aim to analyze the country risk volatility by modelling the conditional variance of sovereign spreads for 24 countries with the standard GARCH $(1,1)$ model introduced by Bollerslev (1986). In particular, we combine the regression model with a GARCH structure of the residuals and use a maximum likelihood estimation procedure. The model has been widely used in the finance literature, playing an important role in financial analysis, option pricing and risk management and capturing many stylized features of financial assets, like volatility clustering, serial correlation and quasi long-range dependence (Taylor, 2008).

Suppose we are observing a discrete economy and denote with $B_{t, i}$ the weekly bond spread of country $i$ in time $t$, for all countries. In order to infer a specific country risk, we define the first differences of bond spreads on a weekly basis,

$X_{i, t}=B_{i, t}-B_{i, t-1}$, for every $i=1, \ldots, 24$ and for every $t=1, \ldots, T_{i}$.

We consider a $\operatorname{GARCH}(1,1)$ model of bond spread differences $X_{t}$ with an intercept, an $\mathrm{AR}(1)$ term and FCD (crisis) dummy in the conditional mean equation. In order to simultaneously model the contemporaneous impact of the crises in both conditional mean and variance, we assume the FCD dummy in the variance equation as well (Kosturov and Stock, 2010). Suppose that in each country $i$ the conditional mean and conditional variance of bonds' spread, given $\mathfrak{J}_{t-1}$, are generated by: 
$X_{i, t}=\mu_{i}+a_{i} X_{i, t-1}+b_{i} F C D_{i, t}+\varepsilon_{i, t}, \quad \varepsilon_{i, t}=\sigma_{i}^{t} \cdot Z_{t}$,

$\sigma_{i, t}^{2}=\omega_{i}+\alpha_{i} \varepsilon_{i, t-1}^{2}+\beta_{i} \sigma_{i, t-1}^{2}+\gamma_{i} F C D_{i, t}$,

where $\mathfrak{I}_{t-1}$ denotes the information set available at time $t-1$, and FCD is the financial crisis dummy indicator, assuming the value of one for dates on and after September 11, 2008, and zero otherwise. Variables $Z_{t}$ are assumed to be independent and identically distributed standard normal random variables, and it is assumed that:

$\omega_{i}>0, \alpha_{i} \geq 0, \beta_{i} \geq 0$, and $\alpha_{i}+\beta_{i}<1$, for every $i=1, . ., 24$

in order to assure the non-negativity and stationarity of the unconditional variance process. If this condition is fulfilled, then the process for the squares, $X_{i, t}^{2}$, is covariance stationary.

For each country $i$ in consideration, the coefficient $b_{i}$ measures changes in the mean bond spread after the financial crisis in September 2008. Because of the negative autocorrelation found in bond spreads for some countries, we allow for the AR(1) term in the conditional mean equation. For a specific set of five countries, namely Greece, Ireland, Italy, Portugal and Spain, in the first-moment equation we additionally assume a dummy variable representing the European debt crisis (EDC). Thus, in these countries we consider the following model:

$$
\begin{aligned}
X_{i, t} & =\mu_{i}+a_{i} X_{i, t-1}+b_{i} F C D_{i, t}+c_{i} E C D+\varepsilon_{i, t}, \quad \varepsilon_{i, t}=\sigma_{i}^{t} \cdot Z_{t}, \\
\sigma_{i, t}^{2} & =w_{i}+\alpha_{i} \varepsilon_{i, t-1}^{2}+\beta_{i} \sigma_{i, t-1}^{2}+\gamma_{i} F C D_{i, t},
\end{aligned}
$$

where the coefficient $c_{i}$ measures changes in the mean bond spread in the event of political announcements/changes. Since the conditional variance is a nonobservable variable, it has to be estimated along with the other parameters of the model. For the estimation of model parameters, we use the maximum likelihood method. For each country $i, i=1, \ldots, 24$, we estimate the conditional variance of bonds' spread from the corresponding equation. 
In the second part of our empirical exercise, we use panel vector autoregression (Holtz-Eakin, Newey and Rosen, 1988; Love and Zicchino, 2006; Abrigo and Love, 2015) in order to examine how changes in volatility of perceived riskiness of a country affect the country's economic outcomes.

Panel vector autoregression is used to complement the multivariate analysis and identify the transmission of shocks. In our analysis we consider the following system of linear equations:

$$
Y_{i, t}=Y_{i, t-1} A_{1}+Y_{i, t-2} A_{2}+\cdots+Y_{i, t-p} A_{p}+u_{i}+\varepsilon_{i, t},
$$

where $Y_{i, t}$ presents a $(1 x k)$ vector of endogenous variables, while $u_{i}$ and $\varepsilon_{i, t}$ are $(1 x k)$ vectors of dependent variable-specific panel fixed effects and idiosyncratic errors, respectively. Parameters required to be estimated are $(k x k)$ matrices $A_{1}, A_{2}, \ldots, A_{p}$.

We model the system of five endogenous variables: sovereign debt conditional variance $\left(\operatorname{cond}_{t}\right)$, output gap (outputgap $\left.{ }_{t}\right)$, harmonized consumer price inflation $\left(p_{t}\right)$, nominal referent interest rates $\left(i r_{t}\right)$ and public debt $\left(p d e b t_{t}\right)$. This variable ordering is also used in Choleski decomposition to identify impulse responses and forecast-error variance decomposition. All variables are transformed to logarithms, and with the exception of conditional variances, all are expressed as first differences. Besides impulse responses and forecast-error variance decomposition, we also report the VAR lag selection criteria, Granger causality test results and roots of VAR companion matrix. The estimation is conducted with a generalized method of moments (GMM) panel, whereby panel fixed effects are removed using forward orthogonal deviation. 


\section{Results}

Table 2 displays results obtained from estimating $\mathrm{GARCH}(1,1)$ models of sovereign bond spreads in first differences. As one can note, in most cases AR(1) terms were not significant in regression and were consequently dropped out of the estimation. Two dummies controlling for the global financial crisis and European debt crisis are only significant in the variance equation. If these two dummies were found to be insignificant and the GARCH model could be estimated without them (thereby assuring that the GARCH stability condition remained satisfied), they were excluded from the estimation. However, in the majority of cases these dummies are either strongly statistically significant or insignificant, but still necessary in the model in order to preserve the GARCH stability condition. This result suggests that in the last decade financial markets in general, and sovereign bond markets in particular, were characterized by several major structural shifts, which in turn created regime changes on sovereign bond markets that one needs to account for when trying to estimate sovereign bond market volatility.

Conditional variance estimates are presented in Figure A1 in the Appendix. Upon observing these figures, one can conclude that the volatility of sovereign spreads increased significantly after the inception of the global financial crisis, even in highly developed European countries which fared through the initial financial crisis and consequent European debt crisis rather smoothly. There are some notable exceptions to this rule: the sovereign bond market volatility in Poland, Germany and Finland did not increase after September 2008, while in the UK the exchange rate mechanism crisis in the early 1990s influenced sovereign bond market volatility more than the 2008 financial crisis. One can also note that sovereign bond markets of the euro zone countries were characterized by very low volatility in the period from the introduction of the common currency to the bankruptcy of Lehman Brothers. 


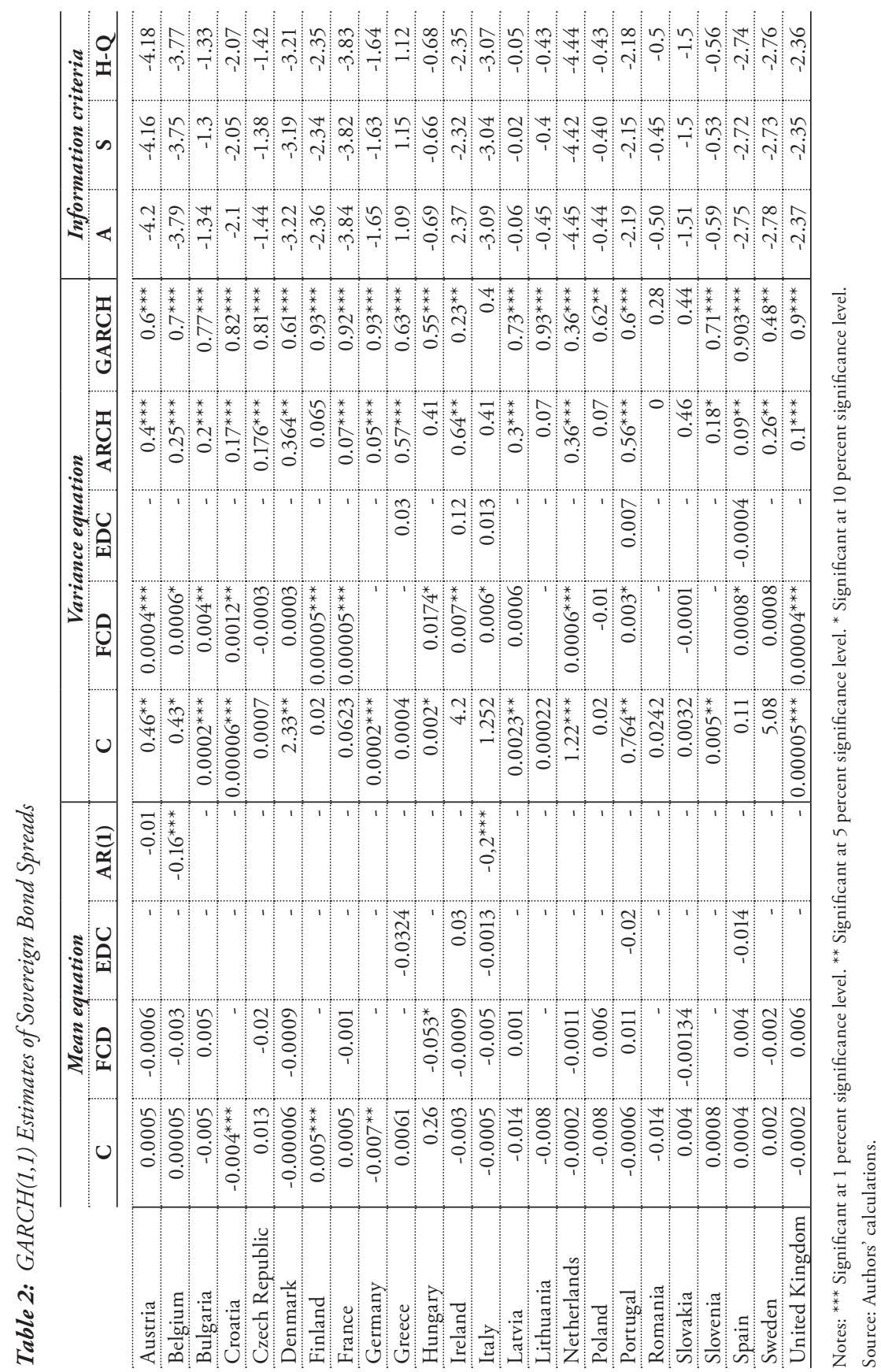


In order to obtain orthogonalized impulse response functions, forecast-error variance decomposition and Granger causality tests, we estimated the panel VAR model using GMM estimation. Lag selection criteria presented in Table A1 in the Appendix suggest estimating the first order VAR. Table A2 suggests the selected VAR is stable, as the modulus of each eigenvalue is strictly less than 1 . Figure 1 displays the orthogonalized impulse response functions obtained after estimating the panel VAR model. ${ }^{2}$ The 95 percent confidence intervals of the impulse responses are computed using 200 Monte Carlo draws based on the estimated model. Impulse response functions presented in the last column of Figure 1 display the response of conditional variance to one standard deviation in macroeconomic variables and conditional variance itself. An unexpected rise in public debt increases the sovereign bond market conditional variance by 0.07 percent two quarters after the initial shock. Conditional variance also increases by approximately 0.2 percent with an unexpected rise in inflation, with this effect being significant even five quarters after the initial shock. Overheating of the economy represented by an output gap increase also positively stimulates the variance, along with an unexpected interest rate hike.

A sudden increase in the conditional variance, which suggests an increase in the general level of country risk, causes a strong and permanent increase in public debt. Namely, immediately after a one percent increase in the conditional variance of sovereign spreads, public debt increases by 0.5 percent. Ten quarters after the initial shock, its effect on public debt is smaller, but still statistically significant. Moreover, it is quite interesting to note that an increase in sovereign bond spreads volatility lowers the output gap, thus depressing the economy. Increased sovereign spreads variance also exhibits deflationary pressures on consumer prices. In both cases, the reaction of macroeconomic variables is statistically significant and does not die out over the observed 10-quarter horizon, although in the case of inflation, the magnitude of the reaction is quite small. We can thus conclude that a sovereign bond market crisis, if described as increased volatility of that market, can result in permanently higher public debt due to increasing borrowing costs, but it can also dampen the economic activity and depress prices.

2 For the purpose of conserving space, panel VAR model estimates are displayed in the Appendix. 


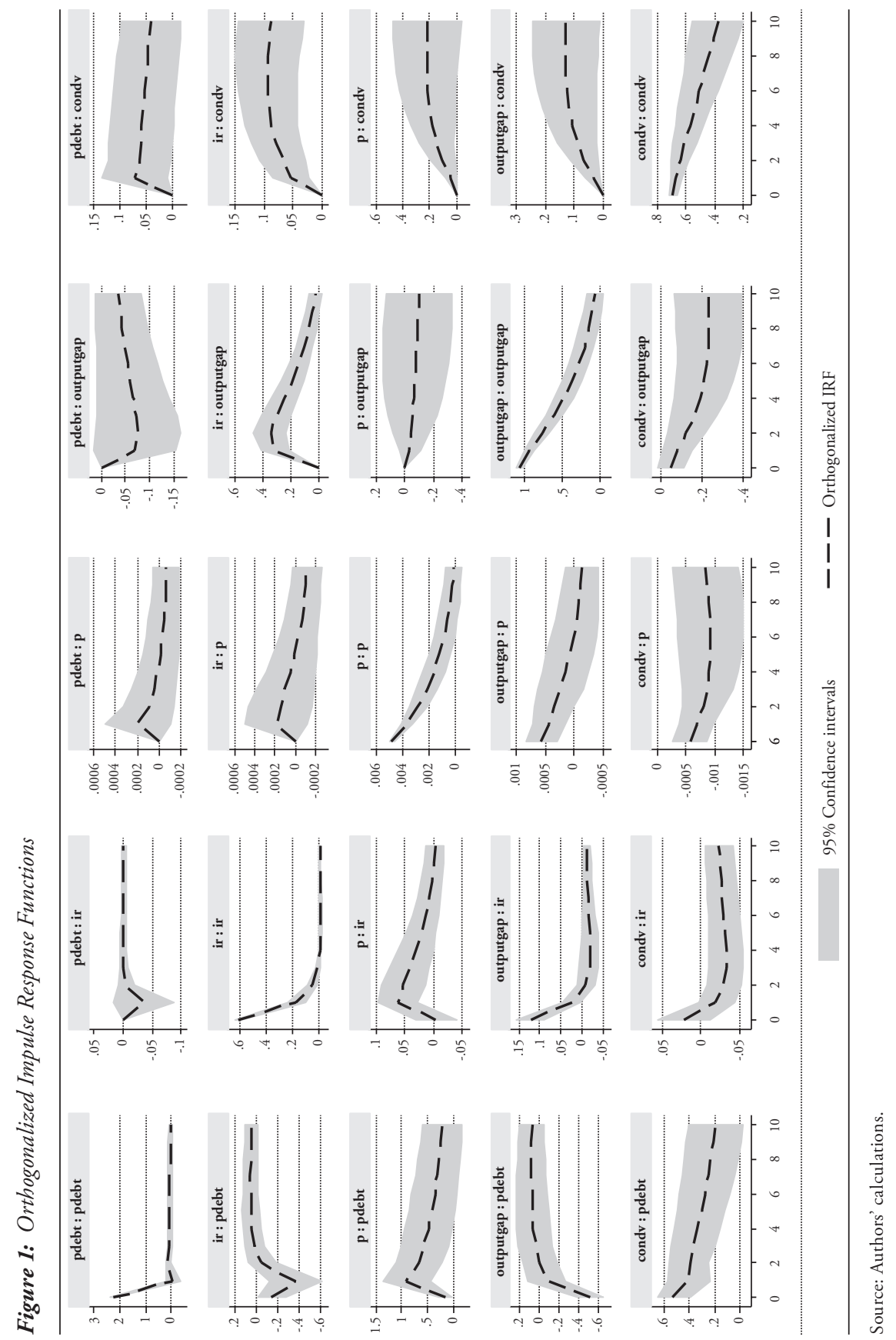


The response of interest rates to an increase in sovereign spreads variance is particularly curious. Immediately after the shock, a rise in interest rates is observed, although it is not statistically significant. This rise can be explained as the attempt of monetary authorities to stabilize the exchange rate immediately after the debt crisis, represented by a surge in variance. However, three quarters later, interest rates fall by 0.03 percent and remain subdued throughout the observed time horizon. The lowering of interest rates represents an attempt of the monetary authorities to stimulate the economy after the debt crisis drove it into a deflationary spiral. Thus, the reaction of interest rates, along with the reaction of the other macroeconomic variables to an unexpected increase of sovereign spreads variance observed from impulse responses, fits quite well into the stylized facts about the behavior of the economy during a financial or debt crisis.

The impulse response results also capture nicely the fundamental relations between macroeconomic variables: an increase in output gap decreases public debt, but stimulates inflation and consequently interest rates. At the same time, an unexpected rise in inflation boosts interest rates and public debt. The results of Granger causality tests reaffirm the main findings from orthogonalized impulse response estimates. Changes in all four macroeconomic variables Granger-cause conditional volatility of sovereign bond markets, although inflation changes are only significant at a 10 percent level of significance. On the other hand, conditional volatility Granger-causes public debt, inflation and interest rates. Block exclusion tests also suggest that conditional volatility Granger-causes output gap, albeit this result is only significant at a 10 percent significance level.

The results of forecast-error variance decomposition suggest that over the 10 -quarter forecast horizon, inflation has the greatest role in explaining the sovereign bond market conditional variance, as it explains up to 8 percent of the entire variance. On the other hand, conditional variance over the same horizon explains up to 12 and 13 percent of public debt and inflation variance, respectively. Conditional variance of sovereign bond markets exerts a somewhat lesser influence on output gap (it helps explain up to 8 percent of its variance) 
and interest rates, where its influence over a horizon of two and a half years is almost negligible.

Table 3: Granger Causality Wald Test

\begin{tabular}{|c|c|c|c|}
\hline Equation & Excluded variable & Chi2 statistic & p-value \\
\hline \multirow{5}{*}{ condv } & outputgap & 6.52 & 0.01 \\
\hline & p & 3.57 & 0.06 \\
\hline & ir & 12.59 & 0.00 \\
\hline & pdebt & 4.17 & 0.04 \\
\hline & ALL & 26.70 & 0.00 \\
\hline \multirow{5}{*}{ outputgap } & condv & 3.27 & 0.07 \\
\hline & $\mathrm{p}$ & 0.43 & 0.51 \\
\hline & ir & 34.13 & 0.00 \\
\hline & pdebt & 2.13 & 0.15 \\
\hline & ALL & 56.07 & 0.00 \\
\hline \multirow{5}{*}{$\mathrm{p}$} & condv & 8.26 & 0.00 \\
\hline & outputgap & 0.08 & 0.78 \\
\hline & ir $\quad$ & 1.55 & 0.21 \\
\hline & pdebt & 1.63 & 0.20 \\
\hline & ALL & 10.30 & 0.04 \\
\hline \multirow{5}{*}{ ir } & condv & 1.17 & 0.28 \\
\hline & outputgap & 5.55 & 0.02 \\
\hline & $\mathrm{p}$ & 16.50 & 0.00 \\
\hline & pdebt & 1.95 & 0.16 \\
\hline & ALL & 31.02 & 0.00 \\
\hline \multirow{5}{*}{ pdebt } & condv & 32.50 & 0.00 \\
\hline & outputgap & 1.78 & 0.18 \\
\hline & p & 15.43 & 0.00 \\
\hline & ir & 8.74 & 0.00 \\
\hline & ALL & 48.47 & 0.00 \\
\hline
\end{tabular}

Source: Authors' calculations. 
Table 4: Forecast-Error Variance Decomposition

\begin{tabular}{|c|c|c|c|c|c|c|}
\hline \multirow{2}{*}{$\begin{array}{l}\text { Response } \\
\text { variable }\end{array}$} & \multirow{2}{*}{$\begin{array}{c}\text { Forecast } \\
\text { horizon }\end{array}$} & \multicolumn{5}{|c|}{ Impulse variable } \\
\hline & & condv & outputgap & $\mathbf{p}$ & ir & pdebt \\
\hline \multirow{5}{*}{ condv } & 1 & 1.00 & 0.00 & 0.00 & 0.00 & 0.00 \\
\hline & 3 & 0.97 & 0.00 & 0.01 & 0.01 & 0.01 \\
\hline & 6 & 0.92 & 0.02 & 0.04 & 0.01 & 0.01 \\
\hline & 8 & 0.89 & 0.02 & 0.07 & 0.01 & 0.01 \\
\hline & 10 & 0.86 & 0.03 & 0.08 & 0.02 & 0.01 \\
\hline \multirow{5}{*}{ outputgap } & 1 & 0.00 & 1.00 & 0.00 & 0.00 & 0.00 \\
\hline & 3 & 0.01 & 0.91 & 0.00 & 0.08 & 0.00 \\
\hline & 6 & 0.03 & 0.85 & 0.00 & 0.10 & 0.01 \\
\hline & 8 & 0.06 & 0.83 & 0.01 & 0.10 & 0.01 \\
\hline & 10 & 0.08 & 0.80 & 0.01 & 0.10 & 0.01 \\
\hline \multirow{5}{*}{$\mathrm{p}$} & 1 & 0.01 & 0.01 & 0.97 & 0.00 & 0.00 \\
\hline & 3 & 0.03 & 0.01 & 0.95 & 0.00 & 0.00 \\
\hline & 6 & 0.07 & 0.01 & 0.92 & 0.00 & 0.00 \\
\hline & 8 & 0.09 & 0.01 & 0.89 & 0.00 & 0.00 \\
\hline & 10 & 0.12 & 0.01 & 0.87 & 0.00 & 0.00 \\
\hline \multirow{5}{*}{ ir } & 1 & 0.00 & 0.04 & 0.00 & 0.96 & 0.00 \\
\hline & 3 & 0.00 & 0.04 & 0.02 & 0.94 & 0.00 \\
\hline & 6 & 0.01 & 0.04 & 0.02 & 0.93 & 0.00 \\
\hline & 8 & 0.02 & 0.04 & 0.02 & 0.92 & 0.00 \\
\hline & 10 & 0.02 & 0.04 & 0.02 & 0.92 & 0.00 \\
\hline \multirow{5}{*}{ pdebt } & 1 & 0.05 & 0.05 & 0.00 & 0.00 & 0.90 \\
\hline & 3 & 0.08 & 0.04 & 0.17 & 0.02 & 0.69 \\
\hline & 6 & 0.11 & 0.03 & 0.23 & 0.02 & 0.60 \\
\hline & 8 & 0.12 & 0.03 & 0.25 & 0.02 & 0.58 \\
\hline & 10 & 0.13 & 0.03 & 0.26 & 0.02 & 0.56 \\
\hline
\end{tabular}

Source: Authors' calculations.

As the ordering of variables in Choleski decomposition can have a significant impact on the results obtained after estimating VAR, we have also tried the reverse ordering in order to test the robustness of the results. We have found that all main findings remain intact. For the purpose of conserving space, we do not report these results in the paper, but they can be obtained upon request from the authors. 


\section{Concluding Remarks}

The aim of this study is to examine whether short-run changes in economic fundamentals can influence the variance of country risk premiums measured by sovereign bond spreads. For that purpose, we use data on sovereign spreads and macroeconomic indicators of interest ranging from 1994 to 2015 for 24 European Union countries. In the first part of the empirical analysis, we estimate conditional variance of sovereign bond spreads, which is then used in the second step along with macroeconomic indicators in order to assess whether changes in business cycle, monetary policy, public indebtedness and inflation affect sovereign spreads variance. In addition to using panel VAR in order to investigate the short-run impact of changes in economic fundamentals on sovereign spreads variance, the panel VAR model can be also exploited to examine whether changes in sovereign spreads variance can have an impact on real economic outcomes.

The outcomes of our empirical investigation strongly suggest that macroeconomic results determine the variance of country risk premiums. An unexpected increase in public debt increases the variance two quarters after the shock. Conditional variance also increases after an unexpected rise in inflation, with this effect being significant even five quarters after the initial shock. Overheating of the economy and unexpected interest rate increases positively stimulate the variance. Granger causality test results corroborate the conclusions obtained from sovereign spreads impulse response functions, as changes in all four macroeconomic variables Granger-cause sovereign spreads variance, albeit inflation changes are only significant at a 10 percent level of significance.

Panel VAR estimates also suggest that changes in sovereign spreads variance result in a strong and permanent increase in public debt, as the reaction of public debt to a sudden increase in sovereign spreads variance does not die out even two and a half years after the initial shock. This finding has important repercussions for public debt management policies, which should aim at stabilizing the variance of sovereign spreads in order to prevent unnecessary permanent debt increases. In 
addition, an increase in sovereign spreads variance is shown to have a permanent adverse effect on the business cycle, as sovereign spreads variance lowers the output gap. It also results in a small, but permanent and statistically significant drop in consumer prices. Having taken all things into consideration, our empirical analysis clearly suggests that policy-makers should pay closer attention to movements of sovereign spreads variance. It is evident from this study that neglecting to do so can have adverse and permanent economic consequences.

\section{Appendix}

Figure A1: Conditional Variance of Sovereign Bond Markets
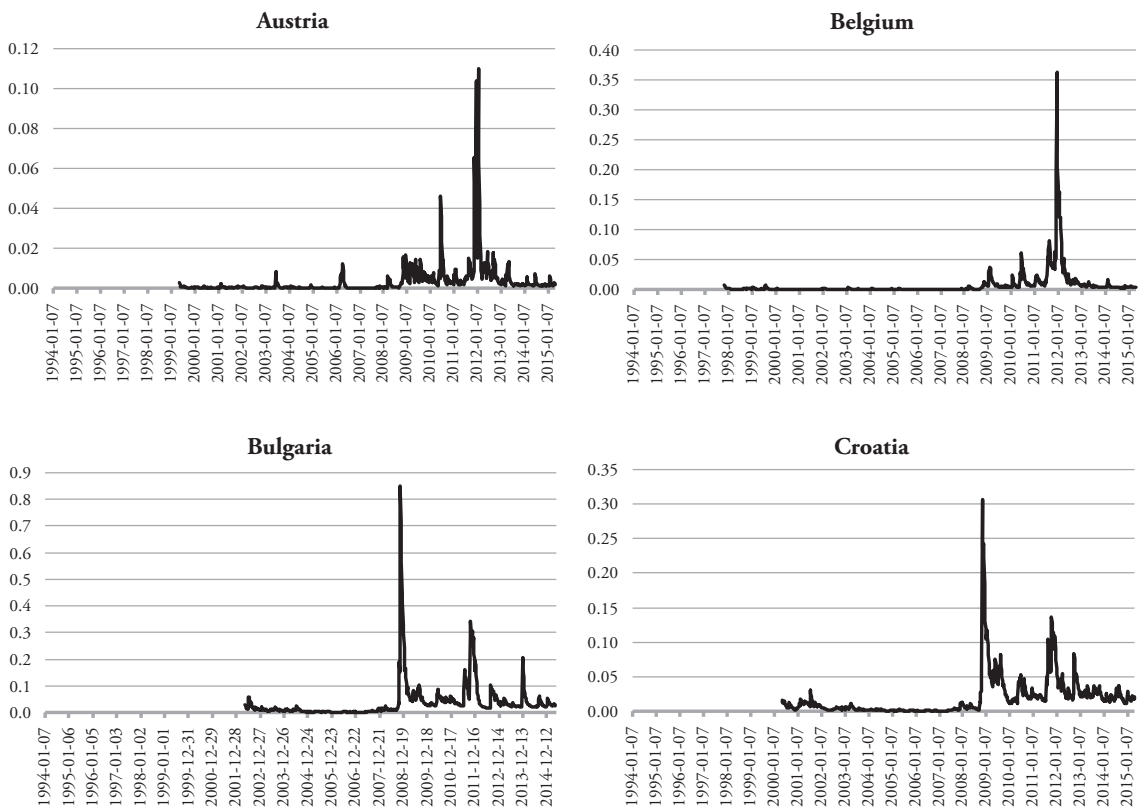
Czech Republic

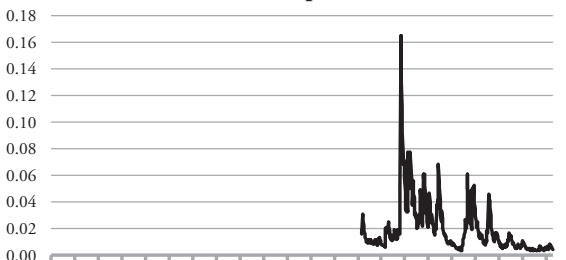

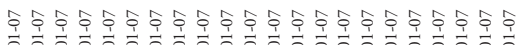

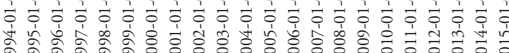

Finland

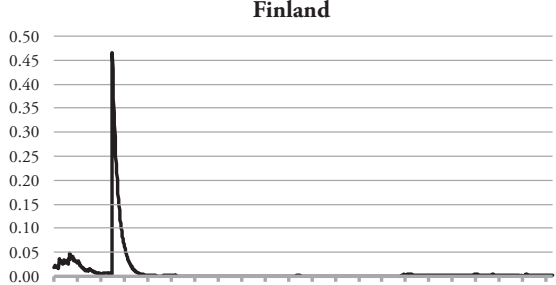

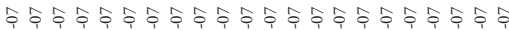

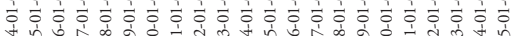

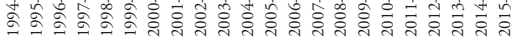

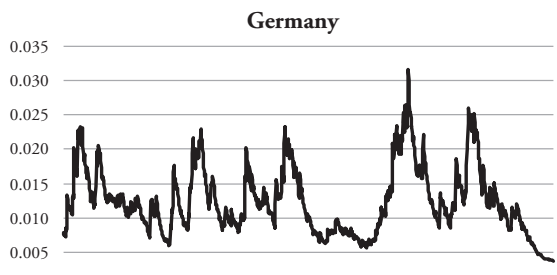

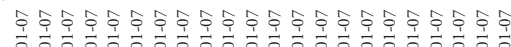

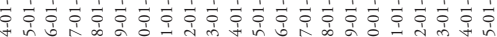

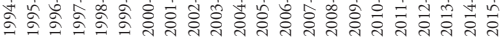

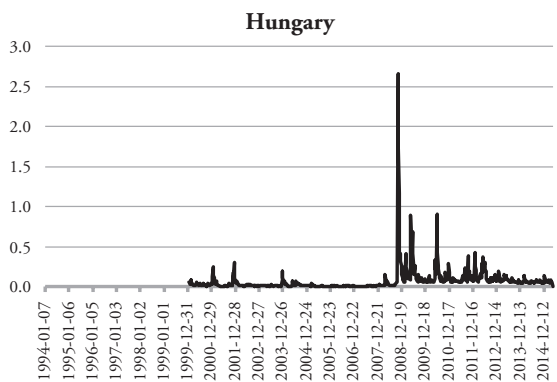

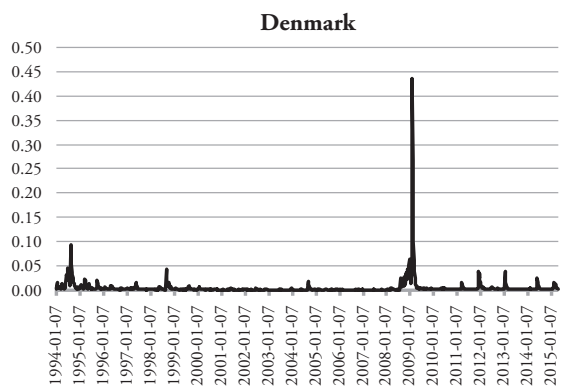

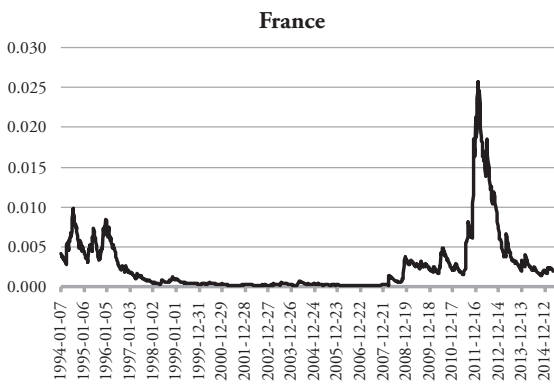

Greece

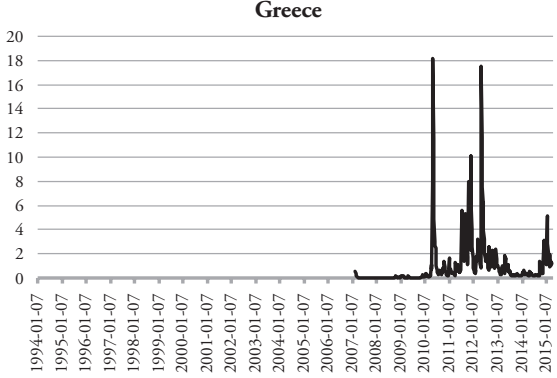

Ireland

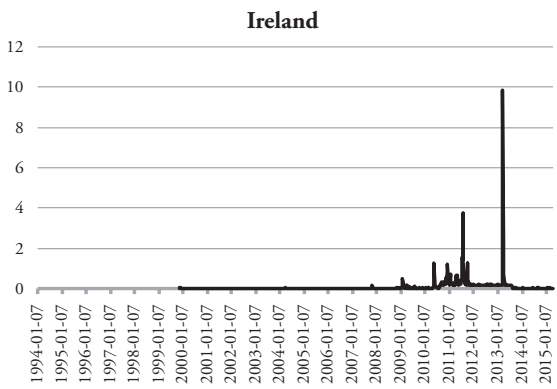


Italy

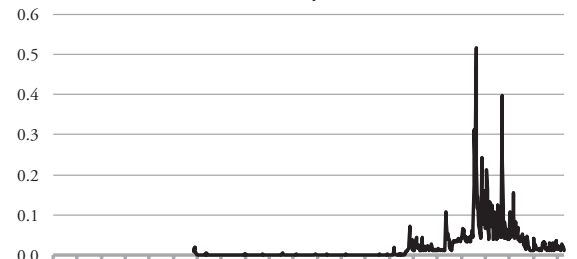

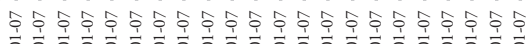

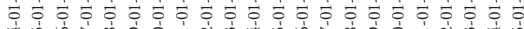

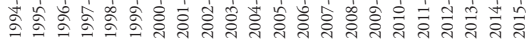

Lithuania

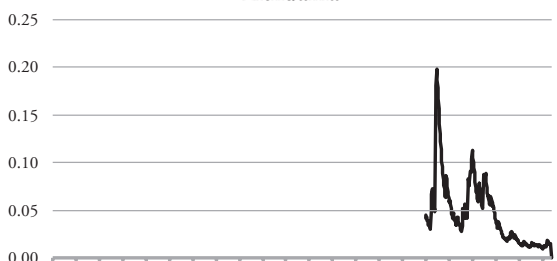

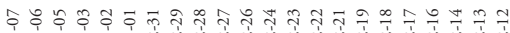

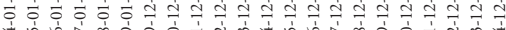

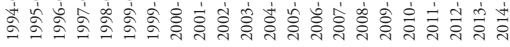

Poland

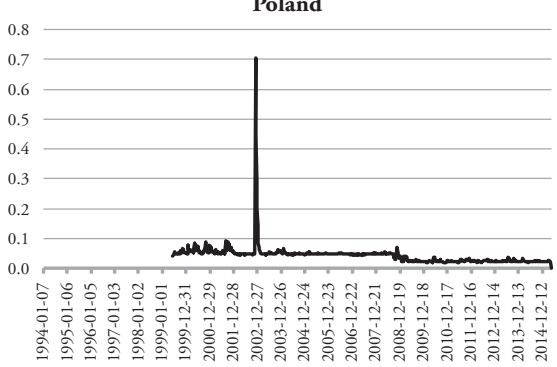

Romania

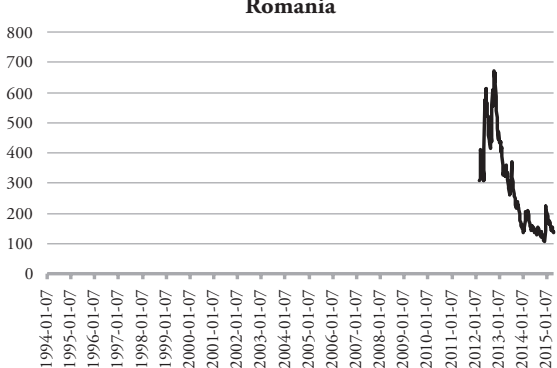

Latvia

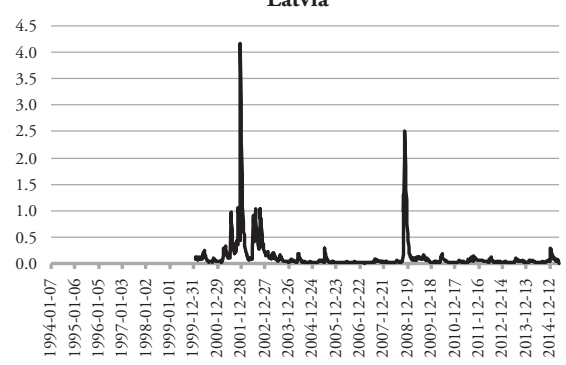

Netherlands

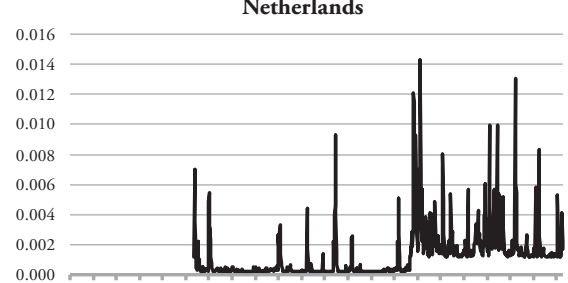

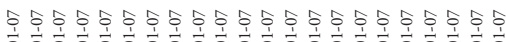

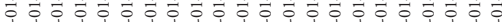

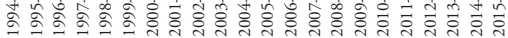
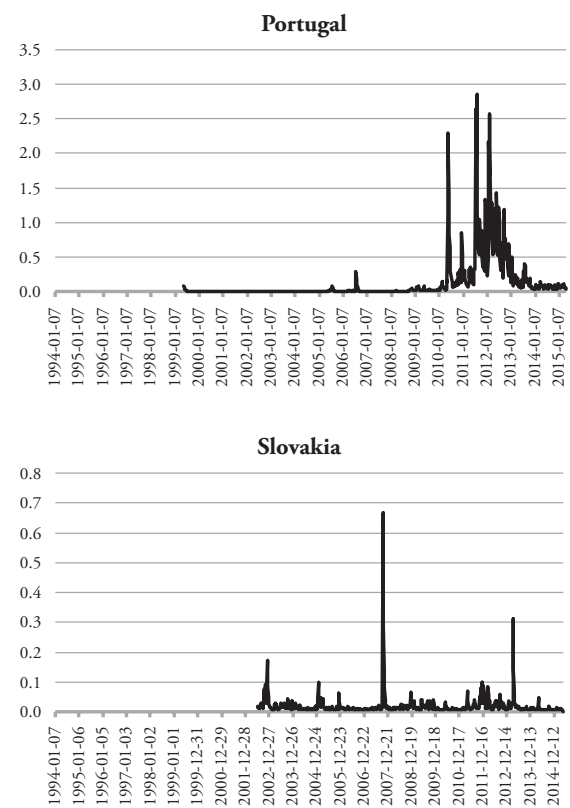


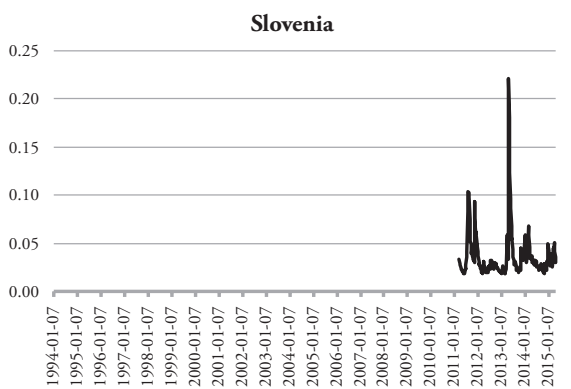

Sweden

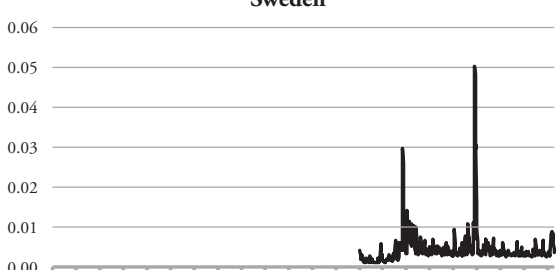

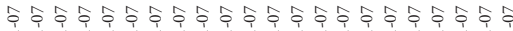

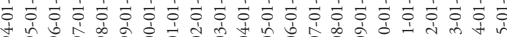

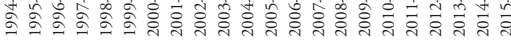
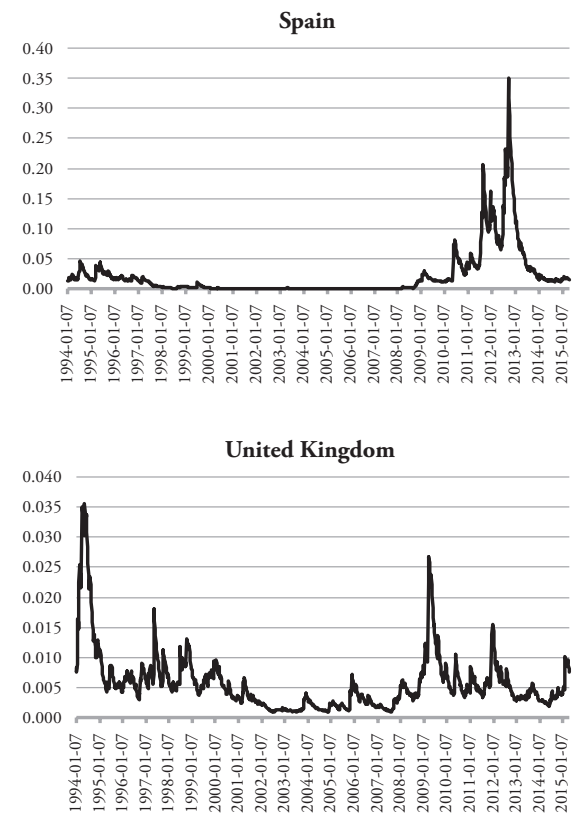

Source: Authors' calculations.

Table A1: Lag Selection Criteria

\begin{tabular}{c|c|c|c}
\hline Lag & MBIC & MAIC & MQIC \\
\hline 1 & -355.8 & 18.5 & -123.2 \\
\hline 2 & -244.3 & 5.3 & -89.2 \\
3 & -151.9 & -27.2 & -74.4 \\
4 & $1.21 \mathrm{E}-29$ & $1.21 \mathrm{E}-29$ & $1.21 \mathrm{E}-29$ \\
\hline
\end{tabular}

Source: Authors' calculations.

Table A2: Moduli of VAR Companion Matrix

\begin{tabular}{|c|c|c|}
\hline \multicolumn{2}{|c|}{ Eigenvalues } & \multirow{2}{*}{ Modulus } \\
\hline Real & Imaginary & \\
\hline 0.8955 & 0 & 0.8955 \\
\hline 0.8611 & 0 & 0.8611 \\
\hline 0.7889 & 0 & 0.7889 \\
\hline 0.3266 & 0 & 0.3265 \\
\hline-0.1113 & 0 & 0.1113 \\
\hline
\end{tabular}

Source: Authors' calculations. 
Table A3: Panel VAR Estimates

\begin{tabular}{|c|c|c|c|c|c|c|}
\hline & Coefficient & $\begin{array}{c}\text { Standard } \\
\text { errors }\end{array}$ & z-value & p-value & \multicolumn{2}{|c|}{$95 \%$ confidence interval } \\
\hline \multicolumn{7}{|l|}{$\operatorname{condv}_{\mathrm{t}}$} \\
\hline $\operatorname{condv}_{\mathrm{t}-1}$ & 0.95 & 0.02 & 38.39 & 0.00 & 0.90 & 1.00 \\
\hline outputgap $_{t-1}$ & 0.03 & 0.01 & 2.55 & 0.01 & 0.01 & 0.06 \\
\hline$p_{t-1}$ & 8.66 & 4.59 & 1.89 & 0.06 & -0.33 & 17.6 \\
\hline $\mathrm{ir}_{\mathrm{t}-1}$ & 0.09 & 0.03 & 3.55 & 0.00 & 0.04 & 0.15 \\
\hline pdebt $_{\mathrm{t}-1}$ & 0.03 & 0.02 & 2.04 & 0.04 & 0.00 & 0.06 \\
\hline \multicolumn{7}{|l|}{ outputgap $_{t}$} \\
\hline $\operatorname{condv}_{t-1}$ & -0.06 & 0.03 & -1.81 & 0.07 & -0.12 & 0.01 \\
\hline outputgap $_{t-1}$ & 0.81 & 0.02 & 35.76 & 0.00 & 0.77 & 0.86 \\
\hline$p_{t-1}$ & -5.70 & 8.72 & -0.65 & 0.51 & -22.8 & 11.4 \\
\hline $\mathrm{ir}_{\mathrm{t}-1}$ & 0.50 & 0.09 & 5.84 & 0.00 & 0.33 & 0.67 \\
\hline pdebt $_{t-1}$ & -0.03 & 0.02 & -1.46 & 0.15 & -0.07 & 0.01 \\
\hline \multicolumn{7}{|l|}{$p_{t}$} \\
\hline $\operatorname{condv}_{\mathrm{t}-1}$ & 0.00 & 0.00 & -2.87 & 0.00 & 0.00 & 0.00 \\
\hline outputgap $_{\mathrm{t}-1}$ & 0.00 & 0.00 & 0.28 & 0.78 & 0.00 & 0.00 \\
\hline $\mathrm{p}_{\mathrm{t}-1}$ & 0.75 & 0.05 & 15.68 & 0.00 & 0.66 & 0.84 \\
\hline$i r_{t-1}$ & 0.00 & 0.00 & 1.25 & 0.21 & 0.00 & 0.00 \\
\hline pdebt $_{t-1}$ & 0.00 & 0.00 & 1.28 & 0.20 & 0.00 & 0.00 \\
\hline \multicolumn{7}{|l|}{$\mathbf{i r}_{\mathrm{t}}$} \\
\hline condv $_{\mathrm{t}-1}$ & -0.02 & 0.02 & -1.08 & 0.28 & -0.05 & 0.01 \\
\hline outputgap $_{t-1}$ & -0.02 & 0.01 & -2.36 & 0.02 & -0.04 & 0.00 \\
\hline $\mathrm{p}_{\mathrm{t}-1}$ & 13.64 & 3.36 & 4.06 & 0.00 & 7.06 & 20.23 \\
\hline $\mathrm{ir}_{\mathrm{t}-1}$ & 0.28 & 0.06 & 4.78 & 0.00 & 0.17 & 0.40 \\
\hline pdebt $_{\mathrm{t}-1}$ & -0.02 & 0.01 & -1.4 & 0.16 & -0.04 & 0.01 \\
\hline \multicolumn{7}{|l|}{ pdebt $_{t}$} \\
\hline condv $_{\mathrm{t}-1}$ & 0.77 & 0.14 & 5.7 & 0.00 & 0.51 & 1.04 \\
\hline outputgap $_{t-1}$ & -0.12 & 0.09 & -1.33 & 0.18 & -0.30 & 0.06 \\
\hline$p_{t-1}$ & 189.5 & 48.2 & 3.93 & 0.00 & 94.9 & 284 \\
\hline $\mathrm{ir}_{\mathrm{t}-1}$ & -0.61 & 0.21 & -2.96 & 0.00 & -1.01 & -0.21 \\
\hline pdebt $_{\mathrm{t}-1}$ & -0.03 & 0.07 & -0.45 & 0.65 & -0.18 & 0.11 \\
\hline \multicolumn{7}{|c|}{ No. of obs $=1111$} \\
\hline \multicolumn{7}{|c|}{ No. of panels $=24$} \\
\hline \multicolumn{7}{|c|}{ Ave. no. of $\mathrm{T}=46.3$} \\
\hline \multicolumn{7}{|c|}{ Final GMM criterion $Q(b)=0.135$} \\
\hline
\end{tabular}

Source: Authors' calculations. 


\section{Literature}

Abrigo, Michael R. M. and Inessa Love, 2015, "Estimation of Panel Vector Autoregression in Stata: A Package of Programs", manuscript, February 2015, http://paneldataconference2015.ceu.hu/Program/Michael-Abrigo.pdf (accessed December 15, 2015).

Aizenman, Joshua, Michael Hutchison and Yothin Jinjarak, 2013, "What is the Risk of European Sovereign Debt Defaults? Fiscal Space, CDS Spreads and the Market Pricing of Risk", Journal of International Money and Finance, 34, pp. 37-59. https://doi.org/10.1016/j.jimonfin.2012.11.011

Alexopoulou, Ioana, Irina Bunda and Annalisa Ferrando, 2010, "Determinants of Government Bond Spreads in New EU Countries", Eastern European Economics, 48(5), pp. 5-37. https://doi.org/10.2753/EEE0012-8775480502

Assenmacher-Wesche, Katrin and Stefan Gerlach, 2008, "Monetary Policy, Asset Prices and Macroeconomic Conditions: A Panel-VAR Study", National Bank of Belgium Working Paper, No. 149, Brussels: National Bank of Belgium. https:// doi.org/10.2139/ssrn.1685105

Baldacci, Emanuele, Sanjeev Gupta and Amine Mati, 2008, "Is It (Still) Mostly Fiscal? Determinants of Sovereign Spreads in Emerging Markets", IMF Working Paper, No. 08/259, International Monetary Fund.

Barrios, Salvador, Per Iversen, Magdalena Lewandowska and Ralph Setzer, 2009, "Determinants of Intra-euro Area Government Bond Spreads during the Financial Crisis", Directorate-General for Economic and Financial Affairs (DG ECFIN) Economic Papers, No. 388, Brussels: European Commission.

Beber, Alessandro, Michael W. Brandt and Kenneth A. Kavajecz, 2009, "Flightto-Quality or Flight-to-Liquidity? Evidence from the Euro-Area Bond Market", The Review of Financial Studies, 22(3), pp. 925-957. https://doi.org/10.1093/rfs/ hhm088 
Bellas, Dimitri, Michael G. Papaioannou and Iva Petrova, 2010, "Determinants of Emerging Market Sovereign Bond Spreads: Fundamentals vs Financial Stress", IMF Working Paper, No. 10/281, International Monetary Fund. https://doi. org/10.1596/9780821384831_ch04

Berganza, Juan Carlos, Roberto Chang and Alicia García Herrero, 2004, "Balance Sheet Effects and the Country Risk Premium: An Empirical Investigation", Review of World Economics/Weltwirtschaftliches Archiv, 140(4), pp. 592-612, http:// www.bde.es/f/webbde/SES/Secciones/Publicaciones/PublicacionesSeriadas/ DocumentosTrabajo/03/Fic/dt0316e.pdf (accessed November 10, 2015). https:// doi.org/10.1007/BF02659616

Bernoth, Kerstin, Jürgen Von Hagen and Ludger Schuknecht, 2006, "Sovereign Risk Premiums in the European Government Bond Market", GESY Discussion Paper, No. 151, SFB/TR.

Bollerslev, Tim, 1986, "A Generalized Autoregressive Conditional Heteroscedasticity", Journal of Econometrics, 31(3), pp. 307-327. https://doi. org/10.1016/0304-4076(86)90063-1

Boubtane, Ekrame, Dramane Coulibaly and Christophe Rault, 2013, "Immigration, Growth, and Unemployment: Panel VAR Evidence from OECD Countries", Labour, 27(4), pp. 399-420. https://doi.org/10.1111/labr.12017

Canova, Fabio and Matteo Ciccarelli, 2013, "Panel Vector Autoregressive Models: A Survey" in Thomas B. Fomby, Lutz Kilian and Anthony Murphy, eds., VAR Models in Macroeconomics-New Developments and Applications: Essays in Honor of Christopher A. Sims, pp. 205-246, Bingley: Emerald Group Publishing. https:// doi.org/10.1108/S0731-9053(2013)0000031006

Codogno, Lorenzo, Carlo Favero and Alessandro Missale, 2003, "Yield Spreads on EMU Government Bonds”, Economic Policy, 18(37), pp. 503-532. https://doi. org/10.1111/1468-0327.00114_1 
Dell'Ariccia, Giovanni, Isabel Schnabel and Jeromin Zettelmeyer, 2002, "Moral Hazard and International Crisis Lending: A Test", IMF Working Paper, No. 02/181, International Monetary Fund.

Dumičić, Mirna and Tomislav Ridzak, 2011, "Determinants of Sovereign Risk Premia for European Emerging Markets", Financial Theory and Practice, 35(3), pp. 277-299. https://doi.org/10.3326/fintp.35.3.2

Eaton, Jonathan and Mark Gersovitz, 1980, "LDC Participation in International Financial Markets: Debt and Reserves", Journal of Development Economics, 7(1), pp. 3-21. https://doi.org/10.1016/0304-3878(80)90025-5

Ebner, André, 2009, "An Empirical Analysis on the Determinants of CEE Government Bond Spreads", Emerging Market Review, 10(2), pp. 97-121. https:// doi.org/10.1016/j.ememar.2009.02.001

Edwards, Sebastian, 1984, "LDC Foreign Borrowing and Default Risk: An Empirical Investigation 1976-80", American Economic Review, 74(4), pp. $726-$ 734.

Edwards, Sebastian, 1986, "The Pricing of Bonds and Bank Loans in International Markets: An Empirical Analysis of Developing Countries' Foreign Borrowing”, European Economic Review, 30(3), pp. 565-589. https://doi.org/10.1016/00142921(86)90009-7

Engle, Robert F., 2011, "Long-Term Skewness and Systemic Risk", Journal of Financial Econometrics, 9(3), pp. 437-468. https://doi.org/10.1093/jjfinec/ nbr002

Favero, Carlo, Marco Pagano and Ernst-Ludwig Von Thadden, 2010, "How Does Liquidity Affect Government Bond Yields?", Journal of Financial and Quantitative Analysis, 45(1), pp. 107-134. https://doi:10.1017/S0022109009990494

Feder, Gershon and Richard E. Just, 1977, "A Study of Debt Servicing Capacity Applying Logit Analysis", Journal of Development Economics, 4(1), pp. 25-38. https://doi.org/10.1016/0304-3878(77)90004-9 
Haugh, David, Patrice Ollivaud and David Turner, 2009, "What Drives Sovereign Risk Premiums?”, OECD Working Paper, No.178, OECD Economics Department. https://doi.org/10.1787/222675756166

Hilscher, Jens and Yves Nosbusch, 2010, "Determinants of Sovereign Risk: Macroeconomic Fundamentals and the Pricing of Sovereign Debt", Review of Finance, 14(2), pp. 235-262. https://doi.org/10.1093/rof/rfq005

Holtz-Eakin, Douglas, Whitney Newey and Harvey S. Rosen, 1988, "Estimating Vector Autoregressions with Panel Data", Econometrica, 56(6), pp. 1371-1395. https://doi.org/10.2307/1913103

Ivanov, Marijana, Marina Tkalec and Maruška Vizek, 2011, "The Determinants of Financial Euroization in a Post-Transition Country: Do Threshold Effects Matter?", Finance a Uver, 61(3), pp. 230-251, http://journal.fsv.cuni.cz/ storage/1213_vizek.pdf (accessed November 20, 2015).

Kiyotaki, Nobuhiro and John Moore, 1997, "Credit Cycles", Journal of Political Economy, 105(2), pp. 211-248. https://doi.org/10.1086/262072

Kosturov, Nikolay and Duane Stock, 2010, “The Sensitivity of Corporate Bond Volatility to Macroeconomic Announcements" in Cheng-Few Lee, Alice C. Lee and John Lee, eds., Handbook of Quantitative Finance and Risk Management, pp. 883-913, New York, NY: Springer Science+Business Media. https:/doi. org/10.1007/978-0-387-77117-5_58

Love, Inessa and Lea Zicchino, 2006, "Financial Development and Dynamic Investment Behavior: Evidence from Panel VAR", The Quarterly Review of Economics and Finance, 46(2), pp. 190-210. https://doi.org/10.1016/j. qref.2005.11.007

Malone, Samuel W., 2009, "Balance Sheet Effects, External Volatility, and Emerging Market Spreads”, Journal of Applied Economics, 12(2), pp. 273-299. https://doi.org/10.1016/S1514-0326(09)60016-7 
Manganelli, Simone and Guido Wolswijk, 2009, "What Drives Spreads in the Euro Area Government Bond Market?”, Economic Policy, 24(58), pp. 191-240. https://doi.org/10.1111/j.1468-0327.2009.00220.x

Min, Hong-Ghi, Duk-Hee Lee, Changi Nam, Myeong-Cheol Park and Sang-Ho Nam, 2003, "Determinants of Emerging-Market Bond Spreads: Cross-Country Evidence”, Global Finance Journal, 14(3), pp. 271-286. https://doi.org/10.1016/j. gf. 2003.10.001

Sachs, Jeffrey D., 1981, “The Current Account and Macroeconomic Adjustment in the 1970s", Brookings Papers on Economic Activity, 1981(1), pp. 201-268. https://doi.org/10.2307/2534399

Seungyeon, Won, Sup Yun Young and Joon Kim Byoung, 2013, "Emerging Bond Market Volatility and Country Spreads", Emerging Markets Finance and Trade, 49(1), pp. 82-100. https://doi.org/10.2753/REE1540-496X490105

Sgherri, Silvia and Edda Zoli, 2009, "Euro Area Sovereign Risk during the Crisis”, IMF Working Paper, No. 09/222, International Monetary Fund.

Taylor, Stephen J., 2008, Modelling Financial Time Series, Second Edition, Singapore: World Scientific Publishing.

Tkalec, Marina, Maruška Vizek and Miroslav Verbič, 2014, "Balance Sheet Effects and Original Sinners' Risk Premiums", Economic Systems, 38(4), pp. 597-613. https://doi.org/10.1016/j.ecosys.2014.05.005

Von Hagen, Jürgen, Ludger Schuknecht and Guido Wolswijk, 2011, “Government Bond Risk Premiums in the EU Revisited: The Impact of the Financial Crisis", European Journal of Political Economy, 27(1), pp. 36-43. https://doi.org/10.1016/j. ejpoleco.2010.07.002 